\title{
ANTAGONISM OF L(-)PANTOTHENIC ACID ON LIPID METABOLISM IN ANIMALS
}

\author{
Shuichi KIMURA, Yuji FURUKAWA, Jun-ichiro WAKASUGI, \\ Yasuyuki ISHIHARA, and Asao NAKAYAMA ${ }^{1}$ \\ Department of Food Chemistry, Faculty of Agriculture, Tohoku University, \\ Tsutsumidori-Amamiya, Sendai 980, Japan
}

(Received December 14, 1979)

\begin{abstract}
Summary The inhibition rate of $\mathrm{L}(-)$ pantothenate as an antagonist of $\mathrm{D}(+)$ pantothenate was discussed from the viewpoint of growth and lipid metabolism. The growth rate of mice given pantothenate-deficient diets containing $\mathrm{L}(-)$ pantothenate $(300 \mathrm{mg}$ per $100 \mathrm{~g}$ diet) was markedly decreased, and such pantothenate-deficient symptoms as "spectacle eyes" appeared. However, it was recovered by the simultaneous addition of $\mathrm{D}(+)$ pantothenate. This result suggests that $\mathrm{L}(-)$ pantothenate is an antagonist of $\mathrm{D}(+)$ pantothenate. The same phenomenon was observed in a rat experiment. The growth of rats given $\mathrm{L}(-)$ pantothenate was extremely poor but recovered by the simultaneous addition of $\mathrm{D}(+)$ pantothenate. Its complete recovery was seen when the ratio of $\mathrm{L}(-)$ pantothenate to $\mathrm{D}(+)$ pantothenate reached $100: 1$. The same tendencies were observed in the liver levels of total lipid, total cholesterol and triglyceride, and also in the lipoperoxide values. This experiment suggests that the inhibition rate of $\mathrm{L}(-)$ pantothenate to $\mathrm{D}(+)$ pantothenate in animals is similar to that of DL- $\omega$-methyl pantothenate.

Keywords L(-)pantothenic acid, D(+)pantothenic acid, $\omega$-methyl pantothenic acid, antagonist, pantothenic acid deficiency, cholesterol, growth inhibition, lipoperoxide, liver lipid
\end{abstract}

In the 1940's, there were reports regarding experiments with microorganisms $(1)$, chicks $(2,3)$ and rats $(3,4)$ that $\mathrm{D}(+)$ pantothenate $(\mathrm{PaA})$ was biologically active, while $\mathrm{L}(-) \mathrm{PaA}$ was completely inactive, and the racemic compound DL-PaA had half the biological activity of $\mathrm{D}(+) \mathrm{PaA}$. Later, these studies were supported by many researchers. Sarett and Barboriak (5) found that $\mathrm{L}(-) \mathrm{PaA}$ had no apparent biological activity when fed with equal amounts of $\mathrm{D}(+) \mathrm{PaA}$, however, a large excess of $\mathrm{L}(-) \mathrm{PaA}$ relative to $\mathrm{D}(+) \mathrm{PaA}$ inhibited the growth of rats. They also observed that the addition of $\mathrm{L}(-) \mathrm{PaA}$ to the diets of $\mathrm{PaA}$-deficient rats aggravated the signs of deficiency and led to more rapid death. On the contrary, $\mathrm{L}(-)$ pantothenyl alcohol did not inhibit utilization of $\mathrm{D}(+) \mathrm{PaA}$. In the

\footnotetext{
1 木村修一, 古川勇次, 若杉潤一郎, 石原靖之, 中山朝男
} 
former report, we showed in mice and rats that the inhibition rate of DL- $\omega$-methyl pantothenate, a $\mathrm{PaA}$ derivative, to $\mathrm{D}(+) \mathrm{PaA}$ was about 100 to $1(6)$. In the present study, we discuss the inhibition rate of $\mathrm{L}(-) \mathrm{PaA}$ as an antagonist of $\mathrm{D}(+) \mathrm{PaA}$ from the viewpoint of growth and lipid metabolism.

\section{Mice}

Male ICR mice (Japan Clea Inc., Tokyo) weighing about $32 \mathrm{~g}$ were divided into three groups of eight animals and kept individually in screen-bottom cages. The first group was given PaA-deficient basal diet, the second PaA-deficient diet containing $12.4 \mathrm{mg}$ of $\mathrm{D}(+) \mathrm{PaA}$ per $100 \mathrm{~g}$ diet and the third PaA-deficient diet containing $300 \mathrm{mg}$ of $\mathrm{L}(-) \mathrm{PaA}$ per $100 \mathrm{~g}$ diet. $\mathrm{L}(-)$ Calcium pantothenate used in this study had a specific rotation of $-27.3^{\circ} \mathrm{C}$. The growth rate of the first group was reduced relative to the second group. In the presence of $\mathrm{L}(-) \mathrm{PaA}$, the growth rate was markedly decreased, the growth stopped at 35 days and such PaAdeficient symptoms as "spectacle eyes" appeared. However, the growth of the animals recovered rapidly by the addition of $\mathrm{D}(+) \mathrm{PaA}$ at 50 days old (Fig. 1). These results show that $\mathrm{L}(-) \mathrm{PaA}$ is an antagonist of $\mathrm{D}(+) \mathrm{PaA}$.

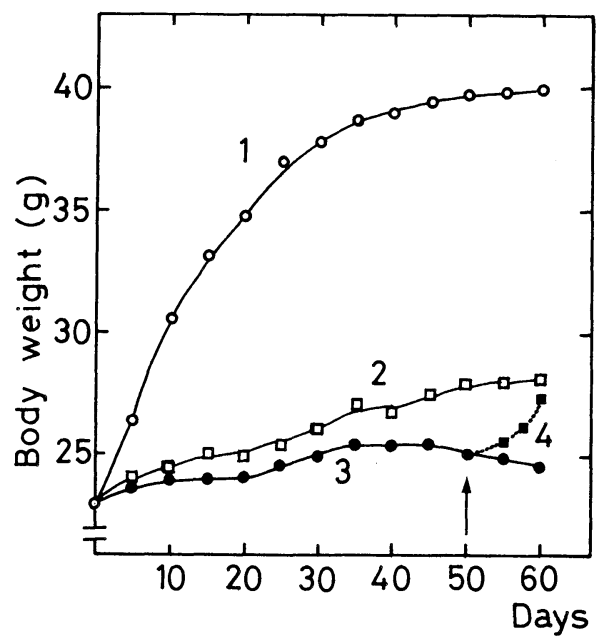

Fig. 1. Effect of $\mathrm{D}(+)$ - and $\mathrm{L}(-)$ pantothenate on the growth of mice. Male weaning mice received pantothenate-deficient diet (curve 2), $\mathrm{D}(+)$ pantothenate-supplemented diet $(12.4 \mathrm{mg} / 100 \mathrm{~g}$ diet, curve 1$), \mathrm{L}(-)$ pantothenate-supplemented diet $(300 \mathrm{mg} / 100 \mathrm{~g}$ diet, curve 3$)$ and $\mathrm{L}(-)$ pantothenate-supplemented diet containing $\mathrm{D}(+)$ pantothenate (arrow, $12.4 \mathrm{mg} / 100 \mathrm{~g}$ diet) after receiving $\mathrm{L}(-)$ pantothenatesupplemented diet for 7 weeks (curve 4). Each plot represents mean values for eight animals in each group. 
Rats

In preliminary experiments on the influence of cholesterol on the growth inhibition by $\mathrm{L}(-) \mathrm{PaA}$, we observed that in the presence of $1 \%$ cholesterol and $300 \mathrm{mg}$ of $\mathrm{L}(-) \mathrm{PaA}$ all the animals died within 6 days. Male weaning rats of Wister strain were separated into five groups of eight animals each. All were housed in individual screen-bottom cages and given five kinds of experimental diets all containing $1 \%$ cholesterol, as shown in Table 1 . After previous maintenance with $\mathrm{PaA}$-deficient diet for 10 days, the rats of five groups were given the experimental diets for five days. The growth of the $\mathrm{L}(-) \mathrm{PaA}$ group was extremely poor, but recovered by the simultaneous addition of $\mathrm{D}(+) \mathrm{PaA}$. Almost complete recovery of the growth rate was seen when the ratio of $L(-) \mathrm{PaA}$ and $\mathrm{D}(+) \mathrm{PaA}$ reached 100:1. As shown in Table 2, the levels of total lipid, total cholesterol and triglyceride in the liver of $\mathrm{PaA}$-deficient rats showed a tendency to decrease. In the $\mathrm{L}(-) \mathrm{PaA}$ group, the concentrations of these lipids were significantly lower than those of the animals fed the pantothenate-supplemented diet. Though no recovery of the liver lipid levels was seen in rats given diets containing $\mathrm{L}(-) \mathrm{PaA}$ and $\mathrm{D}(+) \mathrm{PaA}$ at the ratio of $300: 1$, almost complete recovery was obtained at the ratio of $100: 1$. This experiment suggests that the inhibition rate of $\mathrm{L}(-) \mathrm{PaA}$ in animals is similar to that of DL- $\omega$-methyl PaA (6). The same finding was obtained in the liver TBA value (Fig. 2) which is recognized as being a reflection of lipoperoxide level (7). The liver TBA value was elevated in the PaA-deficient group and further elevated by the addition of $\mathrm{L}(-) \mathrm{PaA}$. However, the elevation could be suppressed by the simultaneous addition of $\mathrm{D}(+) \mathrm{PaA}$. In analogy with the results in liver lipid levels, the elevation of liver TBA value produced by the addition of $\mathrm{L}(-) \mathrm{PaA}$ was

Table 1. Composition of experimental diets. L-PaA, L(-)pantothenate; $\mathrm{D}-\mathrm{PaA}, \mathrm{D}(+)$ pantothenate.

\begin{tabular}{lccccc}
\hline & \multicolumn{6}{c}{ Diet (g/100g diet) } \\
\cline { 2 - 6 } Component & Sufficient & Deficient & $\begin{array}{c}\text { Deficient } \\
+\mathrm{L}-\mathrm{PaA}\end{array}$ & $\begin{array}{c}\text { Deficient } \\
+\mathrm{L}-\mathrm{PaA} \\
+\mathrm{D}-\mathrm{PaA} \\
(300: 1)\end{array}$ & $\begin{array}{c}\text { Deficient } \\
+\mathrm{L}-\mathrm{PaA} \\
+\mathrm{D}-\mathrm{PaA} \\
(100: 1)\end{array}$ \\
\hline Vitamin-free casein & 20 & 20 & 20 & 20 & 20 \\
Glucose & 64.5 & 64.5 & 64.5 & 64.5 & 64.5 \\
Soybean oil & 6 & 6 & 6 & 6 & 6 \\
Salt mixture & 6 & 6 & 6 & 6 & 6 \\
PaA-free vitamin mixture & - & 2 & 2 & 2 & 2 \\
Cholesterol & 1 & 1 & 1 & 1 & 1 \\
Cholic acid & 0.5 & 0.5 & 0.5 & 0.5 & 0.5 \\
L-PaA & - & - & 0.3 & 0.3 & 0.3 \\
D-PaA & 0.01 & - & - & 0.001 & 0.003 \\
\hline
\end{tabular}

Vol. 26, No. 2, 1980 
Table 2. Effect of L-pantothenate on liver lipid in cholesterol-fed rats.

\begin{tabular}{lcccc}
\hline \multicolumn{1}{c}{ Diet } & $\begin{array}{c}\text { Total } \\
\text { lipid }\end{array}$ & $\begin{array}{c}\text { Total } \\
\text { cholesterol } \\
(\mathrm{mg} / \mathrm{g} \text { tissue })\end{array}$ & Triglyceride & Phospholipid \\
\hline $\begin{array}{l}\text { Sufficient } \\
\text { Deficient }\end{array}$ & $69.2 \pm 9.5$ & $10.1 \pm 1.4$ & $20.3 \pm 3.6$ & $21.2 \pm 3.0$ \\
$\begin{array}{l}\text { Deficient } \\
\quad \text { L-PaA }\end{array}$ & $55.7 \pm 11.4$ & $8.6 \pm 1.2$ & $14.7 \pm 8.1$ & $21.1 \pm 3.2$ \\
$\begin{array}{l}\text { Deficient } \\
\quad+\mathrm{L}-\mathrm{PaA},+\mathrm{D}-\mathrm{PaA}\end{array}$ & $56.1 \pm 8.5^{*}$ & $5.0 \pm 1.6^{* *}$ & $13.6 \pm 3.9^{*}$ & $22.6 \pm 1.2$ \\
$\quad(300: 1)$ & & & & \\
$\quad \begin{array}{l}\text { Deficient } \\
+\mathrm{L}-\mathrm{PaA},+\mathrm{D}-\mathrm{PaA}\end{array}$ & $54.2 \pm 10.1$ & $9.1 \pm 1.0^{*}$ & $14.9 \pm 1.7$ & $18.6 \pm 4.8$ \\
$\quad(100: 1)$ & & & & \\
\hline
\end{tabular}

Values represent means \pm SD. ${ }^{*} p<0.05,{ }^{* *} p<0.01$ (compared with sufficient group).

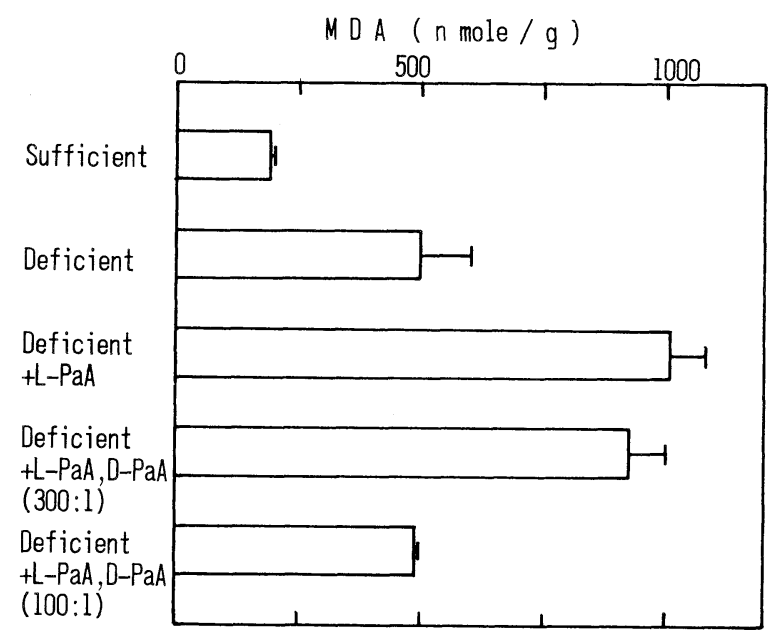

Fig. 2. Effect of $L(-)$ pantothenate on liver TBA values in cholesterol-fed rats. The vertical bar shows the standard error of mean value. MDA, malon dialdehyde.

considerably suppressed at the ratio of $100: 1[\mathrm{~L}(-) \mathrm{PaA}: \mathrm{D}(+) \mathrm{PaA}]$. The findings from these experiments suggest that $\mathrm{L}(-) \mathrm{PaA}$ is useful for the study of $\mathrm{PaA}$ deficiency in animals. 


\section{REFERENCES}

1) Stiller, E. T., Harris, S. A., Finkelstein, J., Keresztesy, J. C., and Folkers, K. (1940): Pantothenic acid. VIII. The total synthesis of pure pantothenic acid. $J$. Am. Chem. Soc., 62, 1785-1790.

2) Babcock, S. H., Jr., and Jukes, T. H. (1940): The biological activity of synthetic pantothenic acid. J. Am. Chem. Soc., 62, 1628.

3) Grüssner, A., Gätzi-Fichter, M., and Reichstein, T. (1940): Krystallisierte Chininsalze des (+)- und (-)-Pantothensäure und die biologische Wirksamkeit der $d(+)$-Pantothensäureäthylesters. Helvet. Chim. Acta, 23, 1276-1286.

4) Kuhn, R., and Wieland, T. (1940): Über die optischen antipoden der Pantothensäure. Chem. Ber., 73, 1134.

5) Sarett, H. P., and Barboriak, J. J. (1963): Inhibition of D-pantothenate by Lpantothenate in the rat. Am. J. Clin. Nutr., 13, 378-384.

6) Kimura, S., and Ariyama, H. (1959): On the nutritive studies of pantothenic acid by antimetabolites. I. Pantothenic acid deficiency produced by $\omega$-methylpantothenic acid in mice. Tohoku J. Agric. Res., 10, 129-135.

7) Masugi, F., and Nakamura, T. (1977): Measurement of thiobarbituric acid value in liver homogenate solubilized with sodium dodecylsulphate and variation of the values affected by vitamin $\mathrm{E}$ and drugs. Vitamins (in Japanese), 51, 21-29. 